\title{
Demineralization of a Low-Rank Coal to Produce Clean Coal for Industrial Utilization
}

\author{
Muhammad Arif Bhatti ${ }^{1}$, Saqib Nasir ${ }^{2 *}$ and Zahid Mehmood ${ }^{1}$ \\ ${ }^{1}$ Mineral Processing Research Centre (MPRC), PCSIR, Lahore, Pakistan \\ ${ }^{2}$ Pakistan Science Foundation (PSF), Ministry of Science and Technology, Islamabad
}

Submission: October 14, 2020; Published: December 09, 2020

*Corresponding author: Saqib Nasir, Pakistan Science Foundation (PSF), Ministry of Science and Technology, Islamabad

\begin{abstract}
An investigation was carried out for the demineralization of a low-rank coal containing high ash $(37.74 \%)$ and sulphur (8.65\%) content to clean it for industrial utilization. The raw coal was evaluated by proximate analysis, total sulphur and Gross Calorific Value (GCV). Run-of-mine coal as received was stage crushed and ground under controlled conditions to fair liberation size. The gravity concentration technology using diagonal deck concentrating table was employed to produce clean coal. A number of gravity separation tests were carried out by varying different parameters i.e. feed size, feed rate, wash water flow rate and deck inclination angle. The final de-mineralized clean coal obtained at optimum conditions contained $13.04 \%$ ash and $2.61 \%$ sulphur and found suitable for many industrial applications.
\end{abstract}

Keywords: Lignite coal; Ash; Sulphur; Gravity Separation; Clean coal

\section{Introduction}

Coal is an important solid fuel which has many important uses worldwide. It is a major source of energy and heat for many industries. But coal combustion causes many environmental problems. Particularly, combustion of coal sulphur contributes to world environmental pollution in the form of $\mathrm{SO}_{2}$ and $\mathrm{SO}_{3}$ which results in acid rain. Both animal and plant life is directly affected due to this pollution [1]. Sulfur of coal occurs in three distinct forms categorized as organic, pyritic and sulphate. The pyritic and sulphate sulfur is relatively easy to remove because pyrite and sulphate particles are heavier than coal. The remaining organic sulfur is a problem because it is chemically bound in the molecular structure of coal and is difficult to remove by physical coal washing methods. This sulfur may be removed after combustion using flue gas desulfurization devices such as scrubbers [2].

Run-of-mine coal has variable quality. It is frequently associated with gangue minerals such as shale, slate, clays, sand, pyrite, sulphate and trace elements. The removal of this associated material helps to prepare the coal according to specification of different industries. It is an important step in reducing the emissions of undesirable gases from coal use and environment protection [3]. Physical coal processing methods reduces most of unwanted impurities like ash forming and sulphur containing minerals of raw coal resulting in lower sulphur dioxide emissions and improved thermal efficiencies [4]. The chemical methods for the demineralization and removal of objectionable impurities of high ash and sulphur from coal by using alkali and acid solutions are also investigated but these are costly [5]. The most popular water based physical processes being practiced all over the world for coal cleaning include washing, scrubbing, dense medium separation, gravity concentration and froth flotation [6]. Coal cleaning before combustion is an effective and efficient method to minimize and remove noncombustible minerals and pollutants and to improve its quality before its utilization $[7,8]$.

Pakistan has large deposits of low quality lignitic to subbituminous coal of tertiary age. Only Punjab province has 235 million tons coal reserves [9]. The Punjab coal fields are situated in the Salt Range and cover an area of about 260 sq. km between Khushab, Dandot and Khewra. But these deposits contain high sulphur and ash content and low calorific value which limit their uses. The main objective of present study was to develop a suitable process for the removal of mineral matter and sulphur present in indigenous low rank coal to acceptable limits for industrial utilization. 


\section{Materials and Methods}

\section{Sample Preparation}

A representative sample of coal was obtained from Habib Ullah Mine near the village of Noori Beera, district Khushab, Salt Range, Punjab Province, Pakistan. The sample was consisted of lumps of variable size ranging from 1 inch to 6 inch. About $100 \mathrm{~kg}$ of coal was collected by coning-quartering technique. The asreceived coal sample was stage crushed by laboratory size jaw crusher to get the product of about half inch down. It was again crushed in roll crusher to achieve the size of quarter inch down. Its size was further reduced by hammer mill to desired size. The riffling technique of sampling was applied to prepare head sample for proximate analysis, ultimate analysis (sulphur only) and gross calorific value determination. The remaining coal was kept in plastic bags for laboratory scale coal cleaning tests.

\section{Proximate and Ultimate Analysis}

The proximate analysis of a representative sample of coal was performed in accordance with ASTM Standard [10]. Total moisture in coal was determined by heating the sample at $105^{\circ} \mathrm{C}$ for one hour in electric oven. Ash was determined by combustion of coal gradually in electric furnace at $750^{\circ} \mathrm{C}$ in four hours. Volatile matter was found by controlled heating the coal at $930^{\circ} \mathrm{C}$ for 7 minutes. Fixed carbon was calculated by difference. Total sulphur was determined gravimetrically by using Eschka mixture [11]. The Gross Calorific Value (GCV) was determined by standard procedure [12] using Bomb Calorimeter. The proximate analysis, ultimate analysis (sulphur only) and gross calorific value of the representative sample of coal are presented in Table 1. Similarly, the evaluation of processed products of gravity concentration and final coal were performed. Chemical analysis of coal ash is shown in Table 2.

Table 1: Proximate analysis, sulphur and gross calorific value of raw coal sample.

\begin{tabular}{|c|c|}
\hline Parameters & Results (ARB) \\
\hline Moisture & $2.44 \%$ \\
\hline Volatile Matter & $24.56 \%$ \\
\hline Ash Content & $37.74 \%$ \\
\hline Fixed Carbon & $35.26 \%$ \\
\hline Total Sulphur & $8.65 \%$ \\
\hline Gross Calorific Value & $5,434 \mathrm{Btu} / \mathrm{lb}$ \\
\hline
\end{tabular}

Table 2: Chemical analysis of coal ash.

\begin{tabular}{|c|c|}
\hline Constituents & Percentage \\
\hline Silica $\left(\mathrm{SiO}_{2}\right)$ & $32.04 \%$ \\
\hline Aluminum Oxide $\left(\mathrm{Al}_{2} \mathrm{O}_{3}\right)$ & $20.46 \%$ \\
\hline Titanium Dioxide $\left(\mathrm{TiO}_{2}\right)$ & $1.80 \%$ \\
\hline Iron Oxide $\left(\mathrm{Fe}_{2} \mathrm{O}_{3}\right)$ & $16.03 \%$ \\
\hline Calcium Oxide $(\mathrm{CaO})$ & $11.82 \%$ \\
\hline
\end{tabular}

\begin{tabular}{|c|c|}
\hline Magnesium Oxide $(\mathrm{MgO})$ & $2.16 \%$ \\
\hline Sodium Oxide $\left(\mathrm{Na}_{2} \mathrm{O}\right)$ & $2.07 \%$ \\
\hline Potassium Oxide $\left(\mathrm{K}_{2} \mathrm{O}\right)$ & $0.74 \%$ \\
\hline Phosphorus Pentoxide $\left(\mathrm{P}_{2} \mathrm{O}_{5}\right)$ & $0.35 \%$ \\
\hline Sulphur as Sulfur Trioxide $\left(\mathrm{SO}_{3}\right)$ & $12.45 \%$ \\
\hline
\end{tabular}

\section{Gravity Concentration Tests}

Gravity separation tests were carried out on ground coal using Diagonal Deck Concentrating Table (Deister Concentrator Company, USA) having a flat diagonal shaped deck (width: $55 \mathrm{~cm}$ x length: $110 \mathrm{~cm}$ ). A series of gravity separation experiments was carried out to optimize the variables of shaking table to achieve maximum reduction of ash and sulphur. The variables such as feed size, feed rate, wash water flow rate and deck inclination angle were varied while number of strokes were fixed at 300 strokes per minute and stroke length at $9 \mathrm{~mm}$. The feed was prepared by grinding the crushed coal in hammer mill. The feed size of coal was varied from $100 \%$ passing 25 to 100 mesh size using British Standard Sieves (BSS). The feed rate of coal was ranged from 6 to $10 \mathrm{~kg} / \mathrm{hr}$, wash water flow rate from 8 to $16 \mathrm{~L} / \mathrm{min}$ and deck inclination angle from $5^{\circ}$ to $9^{\circ}$. The results obtained of tabling tests are shown in Figures 1-4. The proximate analysis, sulphur and gross calorific value of the gravity concentrate coal are shown in Table 3. The optimized conditions of gravity separation test of coal are presented in Table 4. The description of material balance of gravity separation test is given in Table 5 .

Table 3: Proximate analysis, sulphur and gross calorific value of final coal concentrate.

\begin{tabular}{|c|c|}
\hline Proximate Analysis & Dry Basis \\
\hline Moisture & $0.13 \%$ \\
\hline Volatile Matter & $38.36 \%$ \\
\hline Ash & $13.04 \%$ \\
\hline Fixed Carbon & $48.47 \%$ \\
\hline Total Sulphur & $2.61 \%$ \\
\hline GCV & $11,970 \mathrm{Btu} / \mathrm{lb}$ \\
\hline
\end{tabular}

Table 4: Optimized conditions of a typical gravity separation test of coal.

\begin{tabular}{|c|c|c|}
\hline $\begin{array}{c}\text { Shaking Table } \\
\text { Parameters }\end{array}$ & Range of Variables & Optimum Conditions \\
\hline Feed size of Coal & 25 mesh to 100 mesh & $100 \%$ passing 85 mesh \\
\hline Feed rate of Coal & 6 to $10 \mathrm{~kg} / \mathrm{hr}$ & $9 \mathrm{~kg} / \mathrm{hr}$ \\
\hline $\begin{array}{c}\text { Wash water flow } \\
\text { rate }\end{array}$ & 8 to $16 \mathrm{~L} / \mathrm{min}$ & $14 \mathrm{~L} / \mathrm{min}$ \\
\hline $\begin{array}{c}\text { Deck inclination } \\
\text { angle }\end{array}$ & $5^{\circ}$ to $9^{\circ}$ & $8^{\circ}$ \\
\hline Stroke length of deck & (fixed) & $9 \mathrm{~mm}$ \\
\hline $\begin{array}{c}\text { No. of strokes/ } \\
\text { minute }\end{array}$ & (fixed) & 300 cycles/ min \\
\hline
\end{tabular}


Table 5: Material balance of a typical gravity separation test of coal.

\begin{tabular}{|c|c|c|c|c|c|}
\hline \multirow{2}{*}{ Shaking Table Products } & \multirow{2}{*}{ Weight \% } & \multicolumn{2}{|c|}{ Grade } & \multicolumn{2}{|c|}{ Distribution } \\
\hline & & Ash (\%) & S (\%) & Ash (\%) & S (\%) \\
\hline Concentrate & 69.21 & 13.04 & 2.61 & 23.91 & 20.86 \\
\hline Tailing & 30.79 & 93.26 & 22.23 & 76.09 & 79.14 \\
\hline Head Sample & 100 & 37.74 & 8.65 & 100 & 100 \\
\hline
\end{tabular}

\section{Results and Discussion}

The proximate analysis of coal (Table 1 ) shows that it contains $2.45 \%$ moisture, $24.56 \%$ volatile matter, $37.74 \%$ ash content and $35.25 \%$ fixed carbon. The presence of $35.25 \%$ fixed carbon in the coal is sufficient to exploit it on commercial scale to produce clean coal for industrial utilization. High value of ash indicates the presence of significant amount of mineral matter (gangue) contaminated within coal. The gross calorific value of coal was measured to be $5434 \mathrm{Btu} / \mathrm{lb}$. The low heating value also suggests the high amount of gangue components and less amount of combustible matter. The ultimate analysis describes that it has $8.65 \%$ sulphur content. The high sulfur content requires an explanation regarding the origin of sulfur, whether it is of organic or inorganic. These results show that the coal under investigation ranges in rank from lignite to sub-bituminous.

As the coal is a heterogeneous mixture of organic and inorganic matter. The inorganic mineral matter is converted into ash by chemical reactions during the combustion of coal. Coal ash depends upon the types of minerals present in the coal [13]. The high value of ash (37.74\%) content indicates the presence of various gangue minerals. The high iron oxide $(16.03 \%)$ and sulfur content (12.45\%) in the ash (Table 2) indicate the presence of inorganic origin of sulphur (pyrite and sulphate). The significant amount of silica $(32.04 \%)$, alumina $(20.46 \%)$, soda $(2.07 \%)$ and potash $(0.74 \%)$ also depict the presence of clay minerals in coal such as shale, slate and silicates.

As-mined coal (raw coal) contains a mixture of coal together with unwanted impurities. Coal impurities are typically classified as inherent and removable. The inherent impurities cannot be separated economically from the coal during physical coal cleaning processes because these are organically combined with the coal. The removable impurities can be removed using physical processing methods. Various up-gradation methods are employed to remove the non-desirable matter from coal prior to its utilization depending upon the nature of impurities [14]. The specific gravity of coal carbon ranges from 1.6 to 1.9 whereas specific gravity of clays and silicate minerals ranges from 2.6 to 3.5 and pyrite from 5.5 to 6.5 respectively. Due to this significant difference of specific gravity, it was decided to upgrade it by gravity concentration technique which is a density-based process.

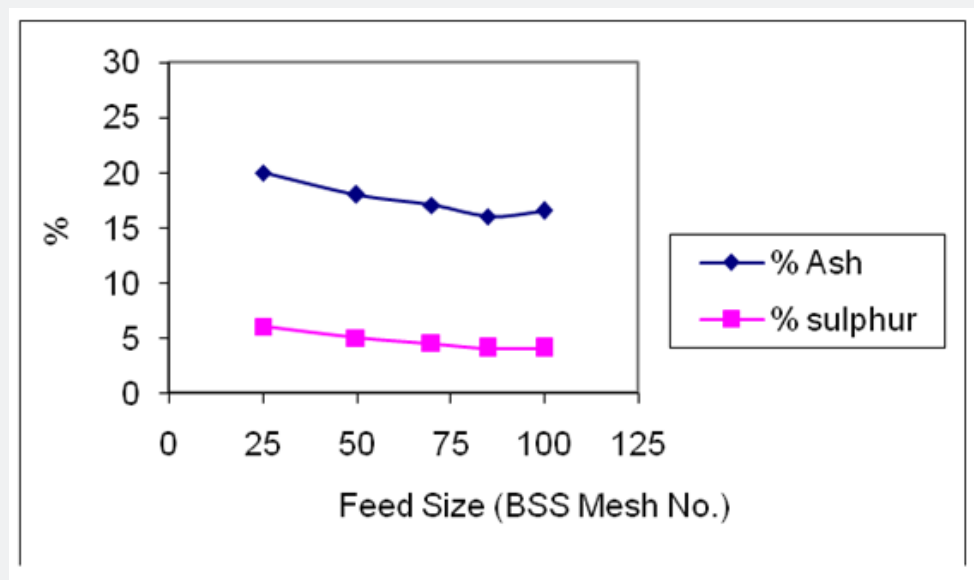

Figure 1: Effect of feed size on ash and sulphur content of coal concentrate.

Different feed sizes of coal were prepared to investigate the effect of feed size on the removal of mineral contaminants (ash and sulphur bearing minerals). The crushed coal was ground in hammer mill followed by rod mill to achieve desired feed sizes. The tabling tests were carried out on feed size of minus 25, 52, 72, 85 and 100 mesh sizes (BSS). The initial experiments were 
performed at arbitrarily chosen conditions i.e. at feed rate of 10 $\mathrm{kg} / \mathrm{hr}$, wash water flow rate of $15 \mathrm{~L} / \mathrm{min}$ and deck inclination angle of $8^{\circ}$. The results in term of reduction in ash and sulphur contents are shown graphically in Figure 1. It can be noted that as the particle size of coal was reduced, a gradual decrease in the ash and sulphur content was observed in the coal concentrate. The best rejection of ash (16.23\%) and sulphur (4.06\%) was obtained when the feed size of minus 85 mesh size was run. This feed size was considered as optimum and selected for onward tabling tests. After that both ash and sulphur content increased slightly which indicates that finer size generates slimes of various impurities which also flow along with water in to coal concentrate. Higher ash and sulphur content at coarser size depicts that coal is not sufficiently liberated from associated gangue minerals [15].

In another set of experiments, feed rate of ground coal was varied from 6-10 $\mathrm{kg} / \mathrm{hr}$ to study its effect on the reduction of ash and sulphur content from the coal. The results are shown in Figure 2 in the form of reduction in ash and sulphur content. It was observed that the optimum results (15.36\% ash) and (3.80\% S) were achieved using a feed rate of $9 \mathrm{~kg} / \mathrm{hr}$. This feed rate gives a sharp separation of coal concentrate from tailings. The grade of coal concentrate dropped above this feed rate due to the fact that the larger amount of feed hinders the proper stratification of the feed over the deck of table leading to some mixing of coal particles and gangue minerals.

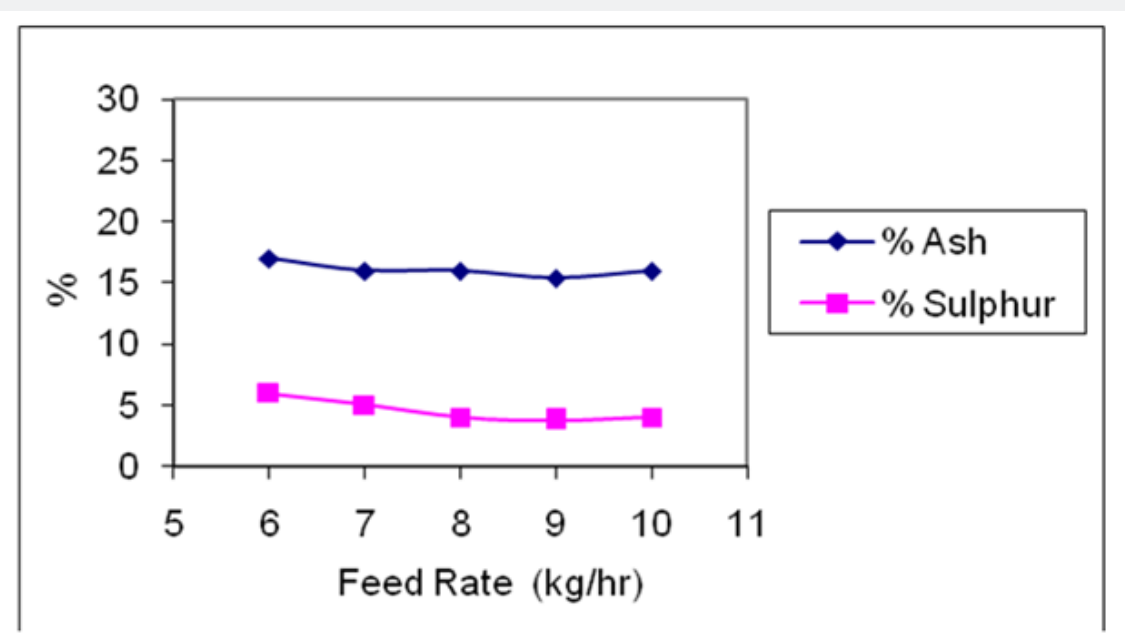

Figure 2: Effect of feed rate on ash and sulphur content of coal concentrate.

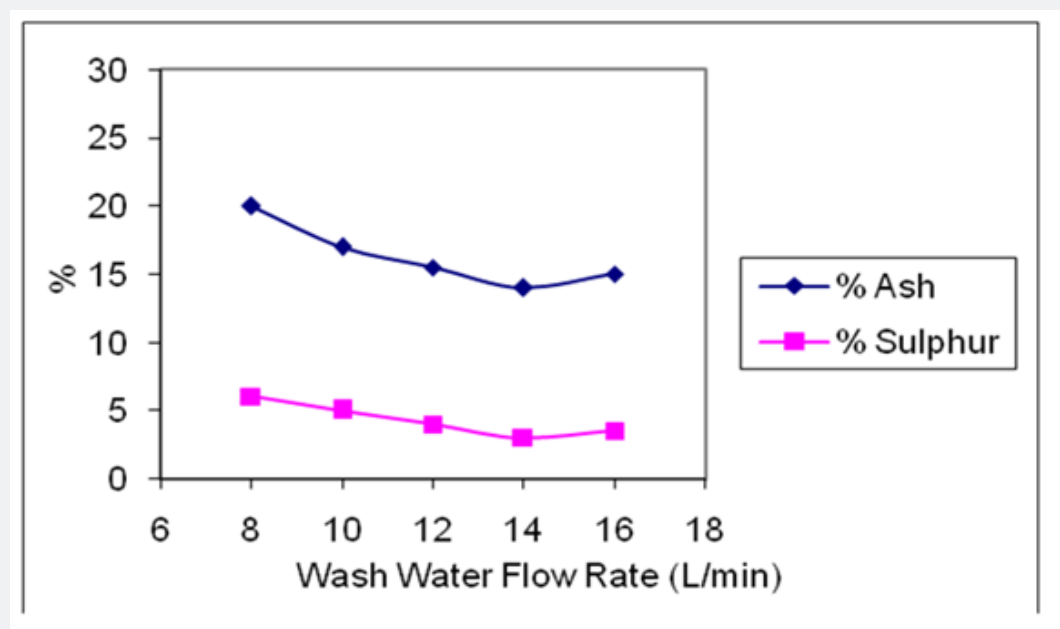

Figure 3: Effect of wash water flow rate on ash and sulphur content of coal concentrate.

The wash water flow rate helps in proper stratification of different minerals depending upon their density, shape and size [16]. The wash water flow rate has been studied by varying it from 8-16 L/min. The results of these tests are shown in Figure 3. It can be seen that the wash water flow rate of $14 \mathrm{~L} / \mathrm{min}$ gave clear separation of coal particles from gangue minerals as the 
percentage of ash was reduced to $14.18 \%$ and sulphur $3.03 \%$ respectively. Above that rate, the percentage of ash and sulphur increased slightly as some fine gangue particles are transferred to coal concentrate because of relatively fast flow of water and below its coal and gangue particles are not properly stratified.

The deck inclination angle is crucial parameter of shaking table as it helps in the efficient separation of minerals. The deck inclination angle was varied from $5^{\circ}$ to $9^{\circ}$ degrees to the horizontal.
The results were plotted in Figure 4. It was found that the best ash and sulphur rejection in the coal concentrate $(13.04 \%$ ash) and $(2.61 \% \mathrm{~S})$ was attained at deck inclination angle of $8^{\circ}$ and then started to decrease. It may be due to the fact that further increase in angle imparts more tendencies to gangue mineral particles to fall down over the cleats of the table. Due to this mixing of impurities (clays, sand and iron pyrite particles) the grade of the coal concentrate was lowered down, and the impurities level was increased as shown graphically [17].

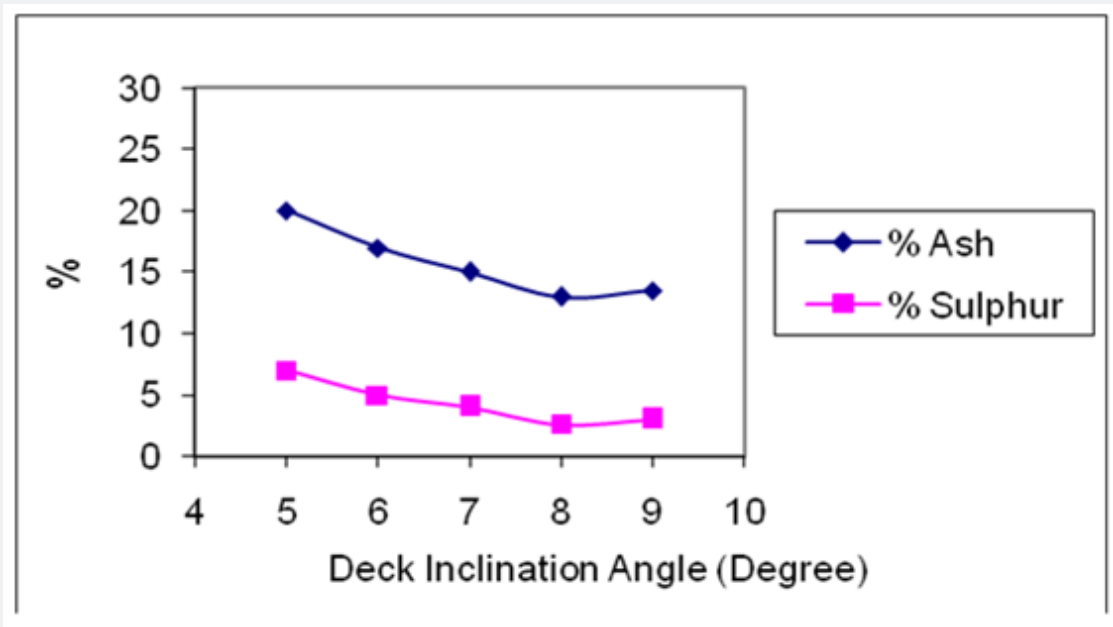

Figure 4: Effect of deck inclination angle on ash and sulphur content of coal concentrate.

The concentrate was evaluated for ash and sulphur content. The proximate analysis of coal concentrate is shown in Table 3. It is clear from this analysis that it contains only small amount of ash $(13.04 \%)$ and sulphur $(2.61 \%)$ as main impurities. The ash content has been reduced from $37.74 \%$ to $13.04 \%$ and sulphur from $8.65 \%$ to $2.61 \%$ in coal concentrate after gravity separation. The shaking table results revealed that the coal sample under investigation was amenable to cleaning by gravity concentration method. It provides excellent ash and sulphur rejection performance by the removal of ash and sulphur beating minerals from the raw coal. The best results were achieved by using a feed size of $100 \%$ passing 85 mesh, feed rate at $9 \mathrm{~kg} / \mathrm{hr}$, wash water flow rate at $14 \mathrm{~L} / \mathrm{min}$ and deck inclination angle at $8^{\circ}$.

The material balance of gravity separation tests (Table 5) indicates that it is possible to obtain a clean coal concentrate containing $48.47 \% \%$ fixed carbon from low rank coal assaying $35.25 \%$ fixed carbon by gravity concentration technique. As a result of gravity-based separation the cumulative ash in the raw coal was reduced from $37.74 \%$ to $13.04 \%$ showing $65.44 \%$ overall reduction from raw coal and similarly the cumulative sulphur was reduced from $8.65 \%$ to $2.61 \%$ in the gravity concentrate exhibiting $69.83 \%$ reduction. Consequently, the \%age of fixed carbon (grade) of coal improved from $35.25 \%$ to $48.47 \%$ corresponding to $37.50 \%$ increase. The gravity separation was found an effective technique for rejecting of high-density ash bearing minerals and sulphur containing pyrite from raw coal at the coarsest possible size and recovering a relatively high-quality clean coal [18-20].

\section{Conclusion}

The proximate analysis, sulphur and Gross Calorific Value (GCV) of Khushab area coal sample shows that it belongs to lignite coal containing relatively high ash and sulphur content. The gravity-based cleaning tests indicated that a comparatively clean coal of $48.47 \%$ fixed carbon with $13.04 \%$ ash and $2.61 \%$ sulphur could be obtained from a low-rank coal assaying $35.25 \%$ fixed carbon, $37.74 \% \%$ ash and $8.65 \%$ sulphur by shaking table method. The optimum results were achieved using a feed size of $100 \%$ passing 85 mesh, feed rate of $9 \mathrm{~kg} / \mathrm{hr}$, wash water flow rate of $14 \mathrm{~L} / \mathrm{min}$ and deck inclination angle of $8^{\circ}$. The developed processing strategy was efficient for the removals of both ash and sulphur bearing mineral matter from coal. The final clean coal produced by this technique was found to be quite suitable for industrial utilization.

\section{References}

1. Fei Y, Aziz A, Nasir S, Jackson WR, Marshall M, et al. (2009) Spontaneous combustion behaviour of some low rank coals and a range of dried products. Fuel 88(9): 1650-1655. 
2. Ehsani MR, Eghbali F (2007) Reduction of sulfur and ash from Tabas coal by froth flotation. Iran J Chem Chem Eng 26(2): 35-40.

3. Ozgen S, Malkoc O, Dogancik C, Sabah E, Sapci FO (2011) Optimization of a multi gravity separator to produce clean coal from Turkish lignite fine coal tailings. Fuel 90(4): 1549-1555

4. Honaker RQ Singh N, Govindarajan B (2000) Application of dense medium in an enhanced gravity separator for fine coal cleaning. Minerals Engineering 13(4): 415-427.

5. Beheraa SK, Chakrabortya S, Meikap BC (2017) Chemical demineralization of high ash Indian coal by using alkali and acid solutions. Fuel 196: 102-109.

6. Honaker RQ Ozsever AV (2003) Innovation in fine coal density separation. In: Advances in gravity concentration, Honaker RQ, Forrest WR (ed.), Society for Mining, Metallurgy and Exploration (SME) Inc Littleton, Colorado, USA, pp. 125.

7. Luttrell G, Zifiqar A, Bratton R, Dynys A, Watters L (2012) Optimal design of fine coal cleaning circuitry. Courtney AY, Gerald HL (ed.) In: Separation Technologies for Minerals, Coal and Earth resources, Society for Mining, Metallurgy and Exploration (SME) Inc. Littleton, Colorado USA pp.139-147.

8. Meshram P, Purohit BK, Sinha MK, Sahu SK, Pandey BD (2015) Demineralization of low-grade coal-A review. Renewable and Sustainable Energy Reviews 41: 745-761.

9. Nasir S, Kucerik J, Mahmood Z (2012) A Study on the Washibility of the Azad Kashmir (Pakistan) Coalfield. Fuel Processing Technology 99: 75-81.

10. ASTM (2007) Standard Test Practice for proximate analysis of coal and coke (D 3172-07). ASTM International, 100 Barr Harbor Drive PO Box C700, West Conshohocken USA 03(5): 347-360.

11. ASTM (2007) Standard Test Method for total sulphur in the analysis of coal and coke (D 3177). ASTM International, 100 Barr Harbor Drive PO Box C700, West Conshohocken, USA 3(5): 365-368.
12. ASTM (2007) Standard Test Method for Gross Calorific Value of coal and coke (D 5865-04). ASTM International, 100 Barr Harbor Drive PO Box C700, West Conshohocken. USA 3(5): 550-557.

13. Mukherjee S, Mahiuddin S, Borthakur PC (2001) Demineralization and Desulfurization of Sub-bituminous Coal with Hydrogen Peroxide. Energy \& Fuels 15: 1418-1524.

14. Harvey RD, Ruch RR (1986) Mineral matter in Illinois and other US coals. Vorres KS (ed.), American Chemical Society, Washington, DC, pp. $10-40$

15. Yuce E, Guney A, Onal G, Kangal O, Kokkılıç O, et al. (2010) Fine Coal Evaluation by Gravity Methods. XXV International Mineral Processing Congress (IMPC), Proceedings / Brisbane, Old, Australia pp. 14291435.

16. Mijał W, Tora B (2018) Development of dry coal gravity separation techniques. Mineral Engineering Conference, IOP Conf. Series: Materials Science and Engineering 427: 1-8.

17. Buzdar KS, Ayub H, Zaheer-ud-din, Ali HA, Ayub J, et al. (2018) Characterization and Washability Studies of Raw Coal of Baluchistan. International Journal of Innovative Research in Advance Engineering Material 4: 286-293.

18. Modiga A, Sosibo N, Singh N, Marape G (2019) A Feasibility Study Evaluating the Efficiency of Fine Coal Washing Using Gravity Separation Methods. The Academic Research Community Publication, pp. 448-456.

19. Majumder AK, Bhoi KS, Barnwal JP (2007) Multi-gravity separator: an alternate gravity concentrator to process coal fines. Minerals \& Metallurgical Processing 24: 133-139.

20. Singh KA, Banerjee PK, Singh PK, Das A (2015) Study of washability characteristics of coals from Seam-IX of Jamadoba Colliery of the Jharia basin, India. Energy Exploration \& Exploitation 33(2): 181-202.

\section{Your next submission with Juniper Publishers} will reach you the below assets

- Quality Editorial service

- Swift Peer Review

- Reprints availability

- E-prints Service

- Manuscript Podcast for convenient understanding

- Global attainment for your research

- Manuscript accessibility in different formats

( Pdf, E-pub, Full Text, Audio)

- Unceasing customer service

Track the below URL for one-step submission https://juniperpublishers.com/online-submission.php 